\title{
Naturally cured foamed concrete with improved thermal insulation properties
}

\author{
Nikolay Mashkin ${ }^{1}$,Ekaterina Bartenjeva ${ }^{1, *}$ and Rustam Mansurov ${ }^{1}$ \\ ${ }^{1}$ Novosibirsk State University of Architecture and Civil Engineering (Sibstrin), 630008 Novosibirsk, \\ Russia
}

\begin{abstract}
The paper is dedicated to investigation on improvement of thermal insulation properties of non-autoclaved concrete by increasing aggregate stability of foamed concrete mixture. The study demonstrates influence of mineral admixtures on the foam stability index in the mortar mixture and on decrease of foamed concrete density and thermal conductivity. The effect of mineral admixtures on thermal conductivity properties of non-autoclaved concrete was assessed through different ways of their addition: to the foam and to the mortar mixture. The admixtures were milled up to the specific surface area of 300 and $600 \mathrm{~m}^{2} / \mathrm{kg}$ using an АГО-9 centrifugal attrition mill with continuous operation mode (Institute of Solid State Chemistry and Mechanochemistry, Siberian Branch of the Russian Academy of Sciences, Novosibirsk). Laboratory turbulent foam concrete mixer was used to prepare foamed concrete. Thermal conductivity coefficient was defined by a quick method using "ИТП-МГ 4 "Zond" thermal conductivity meter in accordance with the regulatory documents. The impact of modifiers on the foam structure stability was defined using the foam stability index for the mortar mixture. The research demonstrated the increase in stability of porous structure of non-autoclaved concrete when adding wollastonite and diopside. Improvement of thermal and physical properties was demonstrated, the decrease of thermal conductivity coefficient reaches $0.069 \mathrm{~W} /\left(\mathrm{m} \times{ }^{\circ} \mathrm{C}\right)$.
\end{abstract}

\section{Introduction}

The growth of interest in cellular concrete investigation is connected with the change of requirements to thermal protection of buildings and structures, particularly those located in harsh climate conditions. Thermal conductivity of foamed concrete can be decreased by creating pores of smaller size [1-3], however, other research show that the size and shape of pores for low-density foamed concretes have no particular impact [4]. There are some research dedicated to mineral content control in hardened cement paste [5], the result of which define the decrease of thermal conductivity coefficient of interpore partitions in foamed concrete by $6.5-24 \%$ with the maximum allowable content of calcium aluminate $\left(\mathrm{C}_{3} \mathrm{~A}\right)$ and calcium alumoferrite $\left(\mathrm{C}_{4} \mathrm{AF}\right)$ in Portland cement and with the minimum allowable content of alite $\left(\mathrm{C}_{3} \mathrm{~S}\right)$. Natural and artificial microsilica [6] is widely used to

* Corresponding author: ek.bartenjeva@yandex.ru 
improve thermal insulation properties of materials, investigations are conducted on the use of carbon nanotubes [7] and geopolymers [8]; however, such technological methods can considerably raise the price of the end product. Thermal conductivity was found to decrease with addition of silica sol (up to 35\%) and wood fiber (up to 30\%) [9]. Use of components with lower thermal conductivity and high density like ash, slag, peat, expanded perlite, vermiculite, also allows improving thermal insulation properties [10-15]. Use of fine montmorillonite clay enables to obtain ultralight foamed concrete with the density of $200 \mathrm{~kg} / \mathrm{m}^{3}$ due to high adsorption capacity [10].

The key factor for thermal conductivity decrease in cellular concretes is the increase of total porosity. Thus, the decrease of mean density by $100 \mathrm{~kg} / \mathrm{m}^{3}$ leads to thermal conductivity reduction by $20 \%$. In this manner, decrease of cellular concrete mean density up to $200 \mathrm{~kg} / \mathrm{m}^{3}$ will cause reduction of thermal conductivity up to $0.06 \mathrm{~W} /\left(\mathrm{m} \times{ }^{\circ} \mathrm{C}\right)$ and lower, which corresponds to that of highly effective thermal insulation materials, such as mineral wool and cellular plastics.

It is difficult to obtain non-autoclaved foamed concrete with low density and thermal conductivity in a production environment. Increase in porosity of foam concrete, especially non-autoclaved one, reduces its structure stability, which goes along with considerable shrinkage, deformation and disturbance of optimum porosity [4, 16-20]. Stability of foamed concrete mixture can be increased by controlling water temperature [17], another effective method for improving aggregate stability is use of fiber admixtures [21-23]. Use of viscosifiers, such as gelatin, carboxymethylcellulose, soluble sodium silicates, also increases the foam structure stability [24-25].

This paper is aimed at investigating technological principles for obtaining nonautoclaved foamed concrete with lower thermal conductivity.

\section{Experiment}

\subsection{Materials}

Portland cement of type ЦЕМ I 42.5 (Iskitim town) with the following chemical composition (wt.\%) was used to obtain foamed concrete: $\mathrm{Na}_{2} \mathrm{O}_{3}-0.41, \mathrm{MgO}-1.94 ; \mathrm{Al}_{2} \mathrm{O}_{3}$ - 4.29; $\mathrm{SiO}_{2}-20.46 ; \mathrm{P}_{2} \mathrm{O}_{5}-0.08 ; \mathrm{K}_{2} \mathrm{O}-0.97 ; \mathrm{CaO}-63.63 ; \mathrm{TiO}_{2}-0.23 ; \mathrm{MnO}-0.09$; $\mathrm{Fe}_{2} \mathrm{O}_{3}-3.69 ; \mathrm{SO}_{3}-1.77$; loss on ignition (LOI) - 2.44. Specific gravity of Portland cement is $3.060 \mathrm{~g} / \mathrm{cm}^{3}$, bulk density $-1.083 \mathrm{~g} / \mathrm{cm}^{3}$. Acidic fly-ash from thermal power station No.5 located in Novosibirsk obtained after burning Kuznetsk hard coal was used as silica filler. Chemical composition of the filler is as follows (wt.\%): $\mathrm{SiO}_{2}-60.77 ; \mathrm{Al}_{2} \mathrm{O} 3-$ 19.45; $\mathrm{Fe}_{2} \mathrm{O}_{3}-5.16 ; \mathrm{CaO}-5.12 ; \mathrm{MgO}-2.10 ; \mathrm{Na}_{2} \mathrm{O}-0.89 ; \mathrm{K}_{2} \mathrm{O}-2.01 ; \mathrm{SO}_{3}-0.54 ; \mathrm{P}_{2} \mathrm{O}_{5}$ $-0.39 ; \mathrm{TiO}_{2}-0.82 ; \mathrm{BaO}-0.20, \mathrm{MnO}-0.07$. Bulk density of fly-ash is $0.885 \mathrm{~g} / \mathrm{cm}^{3}$, specific gravity $-1.870 \mathrm{~g} / \mathrm{cm}^{3}$, sieve residue 008 (by weight) $-4.49 \%$. «FoamCem» protein-based foaming agent (Italy) was used in the production process.

Wollastonite and diopside were used as mineral admixtures. Wollastonite is a mineral pertaining to silicates group of the Altai deposit, its specific gravity is $2.455 \mathrm{~g} / \mathrm{cm}^{3}$, specific surface area was $90 \mathrm{~m}^{2} / \mathrm{kg}$ and $574 \mathrm{~m}^{2} / \mathrm{kg}$. Chemical composition of wollastonite is: $\mathrm{SiO}_{2}-$ $46.1 ; \mathrm{Al}_{2} \mathrm{O}_{3}-2.93 ; \mathrm{Fe}_{2} \mathrm{O}_{3}-4.44 ; \mathrm{CaO}-45.12 ; \mathrm{MgO}-0.9$; LOI - 0.51. In the production process diopside from the Slyudyanskoe deposit with the following chemical composition was used (wt.\%): $\mathrm{CaO}-25.03, \mathrm{MgO}-20.01 ; \mathrm{SiO}_{2}-51.33, \mathrm{Al}_{2} \mathrm{O} 3-1.88 ; \mathrm{Fe}_{2} \mathrm{O}_{3}-0.84$; $\mathrm{MgO}-20.01 ; \mathrm{K}_{2} \mathrm{O}-0.17, \mathrm{TiO}_{2}-0.14 ; \mathrm{LOI}-0.61$; specific gravity $-2.778 \mathrm{~g} / \mathrm{cm}^{3}$, specific surface area $-116 \mathrm{~m}^{2} / \mathrm{kg}$. 


\subsection{Methods of experiment}

Experimental research was performed using samples of naturally cured foamed concrete produced according to the traditional technology with the use of turbulent foam concrete mixer. The foamed concrete composition was selected in compliance with the known techniques [26], the ratio of silica component to binder was 0.6 ; water/solid ratio $=0.49$.

The influence of mineral admixtures on the foam stability was investigated using foam stability index in the mortar mixture. This indicator characterizes foam shrinkage while mixing it with mortar fraction of foamed concrete. It can be related to the processes of coalescence and synaeresis with insufficient structural strength of interpore partitions caused by variation of $\mathrm{pH}$ medium or redistribution of surfactants in disperse system [2728].

The value of foam stability index in the mortar mixture is one of the crucial factors for foamed concrete production, as foam destruction during mineralization causes porous mixture degradation. It was calculated by the formula [29]:

$$
\mathrm{C}_{\mathrm{cp}}^{\mathrm{p}}=\frac{V_{\text {c.p. }}^{\text {por }}}{V_{\text {c.p. }}+V_{\text {foam }}}
$$

where $V_{\text {c.p. }}^{\text {por }}$ - volume of porous cement paste, $\mathrm{ml} ; V_{c . p .}$ - volume of cement paste, $\mathrm{ml} ; V_{\text {foam }}$ - foam volume, $\mathrm{ml}$.

Introduction of mineral admixtures was performed in two different ways: to the foam and to the mortar mixture. The admixtures were milled up to the specific surface area of 300 and $600 \mathrm{~m}^{2} / \mathrm{kg}$ using АГО-9 centrifugal attrition mill with continuous operation mode (Institute of Solid State Chemistry and Mechanochemistry, Siberian Branch of the Russian Academy of Sciences, Novosibirsk). Mean density ( $\rho$ ) was defined after 28 days according to the GOST 12730.1-78. Thermal conductivity coefficient $(\lambda)$ was defined by a quick method using "ИТП-МГ 4 "Zond" thermal conductivity meter in accordance with the GOST 30256-94. Quick method to define thermal conductivity is based on the dynamic method, i.e. on the change rate of averaged temperature of the heat probe (as the first probe temperature derivative with respect to time) in the tested material. The lower thermal conductivity of material is, the slower the probe cools down.

\section{Results}

The values of foam stability in the mortar mixture are given in Table 1.

Table 1. Influence of type, amount and method of mineral admixture introduction on the foam stability index in mortar mixture.

\begin{tabular}{|c|c|c|c|c|c|c|}
\hline \multirow{2}{*}{$\begin{array}{l}\text { Type of } \\
\text { admixture }\end{array}$} & \multirow{2}{*}{$\begin{array}{c}\text { Specific surface area, } \\
\mathrm{m}^{2} / \mathrm{kg}\end{array}$} & \multirow{2}{*}{$\begin{array}{l}\text { Method of admixture } \\
\text { introduction }\end{array}$} & \multicolumn{4}{|c|}{ Amount of admixture, wt. \% } \\
\hline & & & 0 & 1 & 2.5 & 4 \\
\hline \multirow{6}{*}{$\begin{array}{l}\stackrel{0}{\Xi} \\
0 \\
0 \\
0 \\
0 \\
\overline{0} \\
0 \\
3\end{array}$} & \multirow{2}{*}{100} & Foam & \multirow{12}{*}{0.74} & 0.79 & 0.91 & 0.71 \\
\hline & & Mortar mixture & & 0.81 & 0.89 & 0.73 \\
\hline & \multirow{2}{*}{300} & Foam & & 0.84 & 0.84 & 0.85 \\
\hline & & Mortar mixture & & 0.96 & 0.93 & 0.96 \\
\hline & 600 & Foam & & 0.67 & 0.84 & 0.56 \\
\hline & 000 & Mortar mixture & & 0.81 & 0.87 & 0.74 \\
\hline \multirow{6}{*}{$\begin{array}{l}\frac{0}{0} \\
\stackrel{0}{0} \\
\stackrel{0}{0}\end{array}$} & \multirow{2}{*}{100} & Foam & & 1.14 & 0.77 & 0.66 \\
\hline & & Mortar mixture & & 0.91 & 0.93 & 0.66 \\
\hline & \multirow{2}{*}{300} & Foam & & 0.90 & 0.86 & 0.91 \\
\hline & & Mortar mixture & & 0.89 & 0.90 & 0.87 \\
\hline & \multirow{2}{*}{700} & Foam & & 0.96 & 0.87 & 0.84 \\
\hline & & Mortar mixture & & 0.87 & 0.90 & 0.93 \\
\hline
\end{tabular}


The highest values of foam stability index in the mortar mixture correspond to specific surface area of the admixture equal to $300 \mathrm{~m}^{2} / \mathrm{kg}$ and the amount of added wollastonite equal to $1-2.5 \%$. When adding diopside in the amount of $1 \%$ to the foaming agent solution the value of foam stability index increases up to 1.14 .

The foam stability index in porous mortar mixture is higher for foamed concrete with mineral admixtures introduced in the mortar mixture.

For diopside, the best values of mean density correspond to the specific surface area of $100-300 \mathrm{~m}^{2} / \mathrm{kg}$ when adding it to the mortar mixture in the amount of 1 and $2.5 \%$. The optimum amount of admixture for wollastonite is $1-2.5 \%$. Increase of the admixture amount causes increase of foam concrete density (Table 2). Introduction of diopside has bigger effect on decrease of mean density of foam concrete, than introduction of wollastonite. When increasing specific surface area of admixtures the variation of mean density of samples are inconsiderable.

Introduction of diopside and wollastonite allows increasing aggregate stability of foam concrete mixture. Positive effect of wollastonite on foamed concrete structure is possible by means of reinforcement of interpore partitions, which occurs due to its acicular particles. This effect allows reducing plastic shrinkage, limiting sedimentation of the mixture components, which agrees with other research [30-31].

Introduction of admixtures reduces thermal conductivity of foamed concrete (Table 2). When using diopside, thermal conductivity coefficient is slightly lower than when using wollastonite. The lowest values correspond to the specific surface area of admixtures of $100 \mathrm{~m}^{2} / \mathrm{kg}$.

Table 2. Influence of type, amount and method of mineral admixture introduction on the mean density and thermal conductivity of foamed concrete.

\begin{tabular}{|c|c|c|c|c|c|c|c|c|c|c|}
\hline \multirow{3}{*}{$\begin{array}{c}\text { Type of } \\
\text { admixture }\end{array}$} & \multirow{3}{*}{$\begin{array}{c}\text { Specific } \\
\text { surface } \\
\text { area, } \\
\mathrm{m}^{2} / \mathrm{kg}\end{array}$} & \multirow{3}{*}{$\begin{array}{l}\text { Method of } \\
\text { admixture } \\
\text { introduction }\end{array}$} & \multicolumn{8}{|c|}{ Amount, wt. \% } \\
\hline & & & \multicolumn{2}{|c|}{0} & \multicolumn{2}{|c|}{1} & \multicolumn{2}{|c|}{2.5} & \multicolumn{2}{|c|}{4} \\
\hline & & & $\rho$ & $\lambda$ & $\rho$ & $\lambda$ & $\rho$ & $\lambda$ & $\rho$ & $\lambda$ \\
\hline \multirow{6}{*}{ 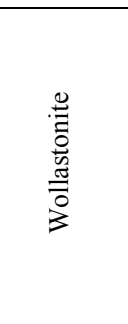 } & \multirow[b]{2}{*}{100} & Foam & \multirow{12}{*}{547} & \multirow{12}{*}{0.122} & 415 & 0.119 & 435 & 0.105 & 638 & 0.122 \\
\hline & & $\begin{array}{l}\text { Mortar } \\
\text { mixture }\end{array}$ & & & 375 & 0.070 & 395 & 0.107 & 449 & 0.114 \\
\hline & \multirow[b]{2}{*}{300} & Foam & & & 420 & 0.082 & 502 & 0.097 & 512 & 0.117 \\
\hline & & $\begin{array}{l}\text { Mortar } \\
\text { mixture }\end{array}$ & & & 420 & 0.075 & 435 & 0.103 & 444 & 0.085 \\
\hline & \multirow[b]{2}{*}{600} & Foam & & & 545 & 0.093 & 404 & 0.104 & 783 & 0.134 \\
\hline & & $\begin{array}{l}\text { Mortar } \\
\text { mixture }\end{array}$ & & & 361 & 0.083 & 406 & 0.095 & 436 & 0.094 \\
\hline \multirow{6}{*}{$\begin{array}{l}\frac{0}{0} \\
\frac{0}{0} \\
\frac{0}{0}\end{array}$} & \multirow[b]{2}{*}{100} & Foam & & & 345 & 0.088 & 560 & 0.108 & 664 & 0.130 \\
\hline & & $\begin{array}{l}\text { Mortar } \\
\text { mixture }\end{array}$ & & & 274 & 0.069 & 377 & 0.097 & 520 & 0.105 \\
\hline & \multirow[b]{2}{*}{300} & Foam & & & 401 & 0.073 & 450 & 0.096 & 563 & 0.079 \\
\hline & & $\begin{array}{l}\text { Mortar } \\
\text { mixture }\end{array}$ & & & 433 & 0.074 & 467 & 0.091 & 477 & 0.091 \\
\hline & \multirow[b]{2}{*}{700} & Foam & & & 488 & 0.101 & 463 & 0.086 & 530 & 0.110 \\
\hline & & $\begin{array}{l}\text { Mortar } \\
\text { mixture }\end{array}$ & & & 434 & 0.084 & 461 & 0.090 & 424 & 0.076 \\
\hline
\end{tabular}

The lowest values of density and thermal conductivity coefficient of foamed concrete are obtained for the minimum amount of introduced admixtures. Apparently, it is connected with the positive effect of mineral admixtures, particularly diopside, on aggregate stability of foamed concrete mixture. Considering that mineral admixtures have reinforcing effect on interpore partitions of foamed concrete, the reinforcement process speeds up when 
introducing the maximum amount of admixture. This can be observed by the high values of foamed concrete density $\left(500-700 \mathrm{~kg} / \mathrm{m}^{3}\right)$. The minimum amount of admixture provides stability of foamed concrete mixture and reinforces interpore partitions to such extent that while mixing mortar and foam the air entrainment occurs, due to which optimum porous structure of foamed concrete is obtained.

As a result of the experiment, dispersity of the admixture was noted to influence the properties of foamed concrete. It is preferable to introduce admixtures with the specific surface area from $300 \mathrm{~m}^{2} / \mathrm{kg}$ and lower.

Adding wollastonite with the specific surface area of $100 \mathrm{~m}^{2} / \mathrm{kg}$ to mortar in the amount of $1 \%$ allows obtaining foamed concrete with the density of $375 \mathrm{~kg} / \mathrm{m}^{3}$ and thermal conductivity coefficient of $0.070 \mathrm{~W} /\left(\mathrm{m} \times{ }^{\circ} \mathrm{C}\right)$. For diopside, the best parameters are as follows: specific surface area is $100 \mathrm{~m}^{2} / \mathrm{kg}$, admixture amount is $1 \%$, type of introduction is to the mortar mixture, foamed concrete density is $274 \mathrm{~kg} / \mathrm{m}^{3}$, thermal conductivity coefficient is $0.069 \mathrm{~W} /\left(\mathrm{m} \times{ }^{\circ} \mathrm{C}\right)$.

\section{Conclusion}

It was found that due to directed control of porous structure of cellular concretes by introducing mineral modifying admixtures it is possible to considerably improve the stability of foam concrete mixture and structure of foamed concrete. This, in turn, is a step to decrease density and thermal conductivity of a material and to reach technical and economical effect due to saving cement. The outcomes of this research allow using production waste for manufacturing of low-density foamed concrete, thus contributing to solving environmental issues.

\section{References}

1. Y.P. Gorlov, Tehnologija teploizoljacionnyh $i$ akusticheskih materialov $i$ izdelij [Technology of thermal insulation and acoustic materials and products] (Vysshaya Shkola Publishers, Moscow, 1989) (in Russian)

2. A.S. Kolomatsky, S.A. Kolomatsky, Construction Materials 1, 38-39 (2003) (in Russian)

3. T.E. Kobidze, V.F. Korovyakov, A.Y. Kiselev, Construction Materials 1, 26-29 (2005) (in Russian)

4. T.V. Anikanova, S.M. Rakhimbaev, Penobetony dlja intensivnyh tehnologij stroitel'stva [Foam concretes for intensive construction technologies] (BGTU Publ., Belgorod, 2015) (in Russian)

5. A.F. Kosach, I.N. Kuznetsova, M.A. Rashchupkina, News of higher educational institutions. Construction 8, 26 - 31 (2009) (in Russian)

6. V.P. Selyaev, V.A. Neverov, L.I. Kupriyashkina, P.V. Selyaev, M.A. Okin, News of higher educational institutions. Construction 4, 30-37 (2014) (in Russian)

7. G. Yakovlev, J. Kerienè, A. Gailius, I. Girnienè, Materials Science 12(2), 147-151 (2006)

8. Z. Zhang, J.L. Provis, A. Reid, H. Wang, Cement and Concrete Composites 62, 97$105(2015)$

9. A.M. Sycheva, E.A. Popova, D.I. Drobyshev, I.P. Filatov, Aktivirovannoe tverdenie penobetonov [Activated hardening of foam concretes] (PGUPS, Saint Petersburg, 2007) (in Russian)

10. L.B. Svatovskaya, V.Y. Solovyeva, V.A. Chernakov, Poluchenie monolitnogo penobetona s uchetom osobennostej prirody zapolnitelja [Obtaining cast foam 
concrete with regard to the nature of filler] (PGUPS, Saint Petersburg, 2001) (in Russian)

11. S.V. Aleksandrovskiy, Prikladnye metody teorii teploprovodnosti i vlagoprovodnosti betona [Applied methods in theory of concrete thermal and moisture conductivity] (Kompanija Sputnik+, Moscow, 2001) (in Russian)

12. N.V. Pavlenko, P.P. Pastushkov, A.N. Kharkhardin, E.V. Voytovich, Vestnik SIBADI 6 (52), 80-86 (2016) (in Russian)

13. E.G. Velichko, Construction Materials 1, 9-13 (2009) (in Russian)

14. A. Kudyakov, I. Prishepa, M. Tolchennikov, IOP Conf. Series: Materials Science Engineering 71, 012016 (2015)

15. R. Demirboğa, R. Gül, Cement and Concrete Research 5(33), 723-727 (2003)

16. V.V. Kondrat'ev, N.N. Morozova, V.G. Khozin, Construction Materials 11, 35-37 (2002) (in Russian)

17. V.N. Morgun, Penobeton [Foam concrete] (RGSU, Rostov-on-Don, 2012) (in Russian)

18. A.I. Kudyakov, A.B. Steshenko, V.V. Konusheva, O.O. Syrkin, Vestnik of TSUAB 5(58), 129-139 (2016) (in Russian)

19. A.K. Abdulin, V.N. Feklistov, Construction Materials 6, $14-17$ (2005) (in Russian)

20. K. Wan, G. Li, Sh. Wang, Ch. Pang, Cement and Concrete Composites 82, 217-226 (2017)

21. A.I. Kudyakov, A.B. Syrkin, Vestnik of TSUAB 2(43), 127-133 (2014) (in Russian)

22. H.R. Shah, J. Weiss, Materials and Structures 9(39), 887-899 (2006)

23. D.-Y. Yooa, N. Banthia, Cement and Concrete Composites 73, 267-280 (2016)

24. V.G. Bezborodov, V.F. Zavadskiy, T.Y. Nikulina, News of higher educational institutions. Construction 12, 29-33 (2002) (in Russian)

25. V.V. Ivanitskiy, A.V. Bortnikov, Y.V. Gudkov, N.A. Sapelin, A.F. Buryanov, patent no. 2213717 Russian Federation (2003) (in Russian)

26. V.F. Zavadskiy, A.F. Kosach, P.P. Deryabin, Stenovye materialy i izdelija [Wall materials and products] (SIBADI Publ., Omsk, 2005) (in Russian)

27. P.M. Kruglyakov, D.R. Ekserova, Pena i pennye plenki [Foam and Foam Films] (Himija, Moscow, 1990) (in Russian)

28. S.M. Rakhimbaev, V.N. Tarasenko, D.V. Tverdokhlebov, Bulletin of BSTU named after V.G. Shukhov 5(1), 119-122 (2003) (in Russian)

29. E.G. Velichko, A.G. Komar, Construction materials 3, 26-29 (2004) (in Russian)

30. N.M. Khasanov, Bulletin of Civil Engineers 3, 181-186 (2016) (in Russian)

31. G.I. Berdov, L.V. Il'ina, V.N. Zyrianova, Vlijanie mineral'nyh mikronapolnitelej na svojstva kompozicionnyh stroitel'nyh materialov [Influence of mineral microfillers on the properties of composite building materials] (NGASU (Sibstrin) Publ., Novosibirsk, 2013) (in Russian) 